\title{
ADOLESCENT IDIOPATHIC SCOLIOSIS AND SIMILAR CONDITIONS: THREE-DIMENSIONAL CLASSIFICATION
}

\author{
ESCOLIOSE IDIOPÁTICA DO ADOLESCENTE E SIMILARES: CLASSIFICAÇÃO \\ TRIDIMENSIONAL
}

\section{ESCOLIOSIS IDIOPÁTICA DEL ADOLESCENTE Y AFECCIONES SIMILARES: CLASIFICACIÓN TRIDIMENSIONAL}

Enguer Beraldo Garcia, ${ }^{1,2}$ Liliane Faria Garcia, ${ }^{1,2}$ Saulo Terror Giesbrecht, ${ }^{1}$ Luis Gustavo Vasconcelos, ${ }^{1}$ Enguer Beraldo Garcia JR, ${ }^{2}$

Marcos Felipe Camarinha, ${ }^{2}$ Eduardo Beraldo Garcia, ${ }^{1}$ Juliana Garcia Camarinha, ${ }^{2}$ Roberto Garcia Gonçalves, ${ }^{1}$ Victor de Oliveira Matos ${ }^{1}$

1. Spine Group of Santa Casa de Belo Horizonte, MG, Brazil.

2. Institute of the Vertebral Column of Belo Horizonte, MG, Brazil.

\begin{abstract}
Objective: To create a new comprehensive, three-dimensional, applicable classification for Adolescent Idiopathic Scoliosis and similar conditions. Methods: The Three-Dimensional Classification was created with three components: the first, the quantitative factor, divides into three types according to the number of curves; the second, the locator factor defines the most structured point of the curve; and the third, the sagittal factor, evaluates the overall sagittal plane. To test the new classification, we studied the images of 99 patients comparing the intra- and interobserver agreement and reproducibility index of the Three-Dimensional Classification with that of Lenke. Results: It can be stated that, overall, the agreement between the three evaluators in relation to the Three-Dimensional Classification and that of Lenke in this series was considered very good. Conclusions: The case study showed a significant difference in the percentages between the two Classifications. In the evaluation of thoracic kyphosis, the Three-Dimensional Classification defined $26.6 \%$ of the cases as hyperkyphosis and $61.6 \%$ as normal, whereas the Lenke Classification defined $6.06 \%$ as hyperkyphosis and $84.18 \%$ as normal. However, in the global comparative analysis of the methods, the Three-Dimensional and Lenke systems presented statistically the same levels of agreement, since the values of the confidence intervals overlap. Level of Evidence II; Retrospective study.
\end{abstract}

Keywords: Scoliosis; Classification; Quantitative analysis.

\section{RESUMO}

Objetivo: Criar uma nova Classificação para escoliose idiopática do adolescente e similares, abrangente, tridimensional e aplicativa. Métodos: Criou-se a Classificação Tridimensional com três componentes: o primeiro denominado de fator quantitativo, que divide-se em três tipos de acordo com o número de curvas; o segundo, o fator localizador evidencia o ponto mais estruturado da curva e o terceiro é o fator sagital que avalia globalmente o plano sagital. Para testar a nova Classificação, estudou-se as imagens de 99 pacientes, comparando o índice de concordância e reprodutibilidade intra e interobsenvador da Classificação Tridimensional com a de Lenke. Resultados: Pode-se afirmar que, no geral, o índice de concordância dos três avaliadores em relação a Classificação Tridimensional e a de Lenke nessa casuística foi considerada muito boa. Conclusões: O estudo da casuística evidenciou diferenças significativas dos percentuais entre as duas Classificações, referente a avaliação da cifose torácica, a Classificação Tridimensional apresentou 26,6\% de hipercifose e normal 61,6\%, ao passo que a Classificação Lenke evidenciou 6,06\% de hipercifose e $84,18 \%$ normal. Contudo, na análise comparativa global, com os métodos Tridimensional e Lenke, apresentou-se estatisticamente os mesmos níveis de concordância, uma vez que os valores dos intervalos de confiança se sobrepõem. Nível de Evidência II; Estudo retrospectivo.

Descritores: Escoliose; Classificação; Análise quantitativa.

\section{RESUMEN}

Objetivo: Crear una nueva clasificación abarcadora, tridimensional y de aplicación para escoliosis idiopática del adolescente y afecciones similares. Métodos: La Clasificación Tridimensional se creó con tres componentes: el primero, el factor cuantitativo, se divide en tres tipos según el número de curvas; el segundo, el factor de localización, define el punto más estructurado de la curva, y el tercero, el factor sagital, evalúa el plano sagital general. Para probar la nueva clasificación, estudiamos las imágenes de 99 pacientes comparando el indice de concordancia y reproducibilidad intra e interobservador de la Clasificación Tridimensional con la de Lenke. Resultados: Es posible afirmar que, en general, el índice de concordancia de los tres evaluadores en relación a la Clasificación Tridimensional y la de Lenke en esa casuística fue considerada muy buena. Conclusiones: El estudio de la casuística mostró una diferencia significativa de los porcentuales entre las dos clasificaciones. En la evaluación de la cifosis torácica, la clasificación tridimensional definió 26,6\% como hipercifosis y 61,6\% como normal, mientras que la Clasificación de Lenke definió el 6,06\% como hipercifosis y el 84,18\% como normal. Sin embargo, en el análisis comparativo global de los sistemas Tridimensional y Lenke presentaron estadísticamente los mismos niveles de concordancia, ya que los valores de los intervalos de confianza se superponen. Nivel de evidencia II; Estudio retrospectivo.

Descriptores: Escoliosis; Clasificación; Análisis cuantitativo. 


\section{INTRODUCTION}

Adolescent idiopathic scoliosis is a three-dimensional spinal deformity that involves curvature of the coronal plane and rotation on the axial axis, with maximum rotational and translational deviations occurring at the apex of the curve. ${ }^{1}$

An adequate scoliosis classification system should allow the surgeon to recommend a specific treatment and to compare the different treatment methods. ${ }^{2}$ In addition, it should be all-encompassing, comprehensive, and consistent with intra- and interobserver analyses. ${ }^{3}$

The first scoliosis classification system was proposed by Schulthess in 1905-1907.4

The King classification system, first published in 1983, evaluates the deformity in the coronal plane, describes five types of thoracic curves, and recommends levels of vertebral segments to be included in the arthrodesis. ${ }^{5}$

The Lenke classification system was developed in 2001 and has three components: the type of curve (1 to 6); the lumbar spine modifier $(A, B$, or $C)$; and the sagittal thoracic modifier (-, N, or +). The six types of curves have specific characteristics in coronal and sagittal radiographs that differentiate the structural and non-structural curves in the proximal thoracic, middle thoracic, and thoracolumbar regions. The lumbar spine modifier is based on the relationship between the central sacral vertical line and the apex of the lumbar curve and the sagittal thoracic modifier is based on the measurement of the sagittal curve from the fifth to the twelfth thoracic level. A minus sign (-) represents a curve of less than 10 degrees, normal $(\mathrm{N})$ represents a curve of 10 to 40 degrees, and a plus sign (+) represents a curve of more than 40 degrees. The lumbar spine modifier is based on the relationship of the center sacral vertical line to the apex of the lumbar curve, and the sagittal thoracic modifier is based on the sagittal curve measurement from the fifth to the twelfth thoracic level. ${ }^{6}$ Five surgeons, members of the Scoliosis Research Society who had developed the new system and who had previously tested the reliability of the King classification on radiographs of twenty-seven patients, measured the same radiographs (standing coronal and lateral as well as supine side-bending views) to test the reliability of the new classification.

The authors evaluated 27 radiographs of patients with adolescent idiopathic scoliosis, applied the Lenke Classification, and observed low intra- and interobserver reproducibility. ${ }^{7}$

In 2008, we published a study applying the Lenke Classification in 66 cases of adolescent idiopathic scoliosis (AIS). There was a greater and statistically significant $(p<0.05)$ discrepancy between the lumbar and sagittal thoracic modifiers. This may have been justified by the low rates of agreement and reproducibility of these variables. ${ }^{8}$

To measure thoracic kyphosis, the authors considered (-) to indicate a hypokyphotic curve less than $25^{\circ},(\mathrm{N})$ to indicate a normal angle between $25^{\circ}$ and $45^{\circ}$, and $(+)$ a hyperkyphotic deformity of greater than $45^{\circ} .9$

That author measured lumbar lordosis of the spine using the Cobb method, obtained by drawing a straight line in the upper plateau of $L 1$ (A) and another in the upper surface of S1 (B). Two straight lines were drawn perpendicular to these lines and their intersection formed the desired angle, the normal value of which ranges from $40^{\circ}$ to $60^{\circ}$. An angle less than $40^{\circ}$ is defined as hypolordosis and an angle greater than $60^{\circ}$ corresponds to hyperlordosis. ${ }^{10}$

Garcia et al. created a new principle of instrumentation in the surgical treatment of AIS and similar conditions, using short, apical, single or multiple fixations, obtaining excellent correction, even better in the more distal curves in relation to the spine. ${ }^{11}$

The objective of this study was to create a new classification system for AIS and similar conditions, called the Three-Dimensional Classification System that covers all formats of these deformities, locating the most structural curve and evaluating the overall sagittal plane.

\section{METHODS}

The project was submitted by the Santa Casa de Belo Horizonte on 05/17/17 and approved as CAAE 68440217.3.0000.5138. The study participants signed the Informed Consent Form.
The Spine Groups of the Instituto da Coluna Vertebral and of the Orthopedics and Traumatology Service of the Santa Casa, both located in Belo Horizonte, had as their objective the creation of a quantitative Three-Dimensional Classification System for AIS and similar conditions, categorizing all deformities into only three basic types, including an overall three-dimensional evaluation using data and knowledge pre-established in the literature. , $^{\text {, }}$

This study considered structural curves greater the $10^{\circ}$ associated with rotation to be scoliosis.

The Three-Dimensional Classification has 3 components: the quantitative factor, the locator factor, and the sagittal factor.

"Quantitative factor": "There are 3 types of deformities": called Type 1, scoliosis with only one curve; Type 2, scoliosis with two curves; and Type 3, scoliosis with three curves. (Figures 1A and 2)

Quantitative Factor, Type 1, One Curve, Type 2, Two Curves, Type 3, Three Curves

"Locator Factor": It is related to the main curve. It was divided into "A, B, and C". It is considered to be " $A$ " when the main curve is located in the proximal region of the spine, extending from the cervical spine to T5; "B" when the most structural curve is in the middle thoracic spine, from T5 to T10; and " $\mathrm{C}$ " when the greatest curve is observed in the thoracolumbar region, from T11 to S1.

"Type 2B" is subdivided into "2BT", when the compensatory curve is located in the proximal region, and " $2 \mathrm{BL}$ ", when the compensatory curve is situated in the thoracolumbar region. (Figures $1 \mathrm{~B}$ and 2 )

Locator factor: locates the most structural curve. If the main curve

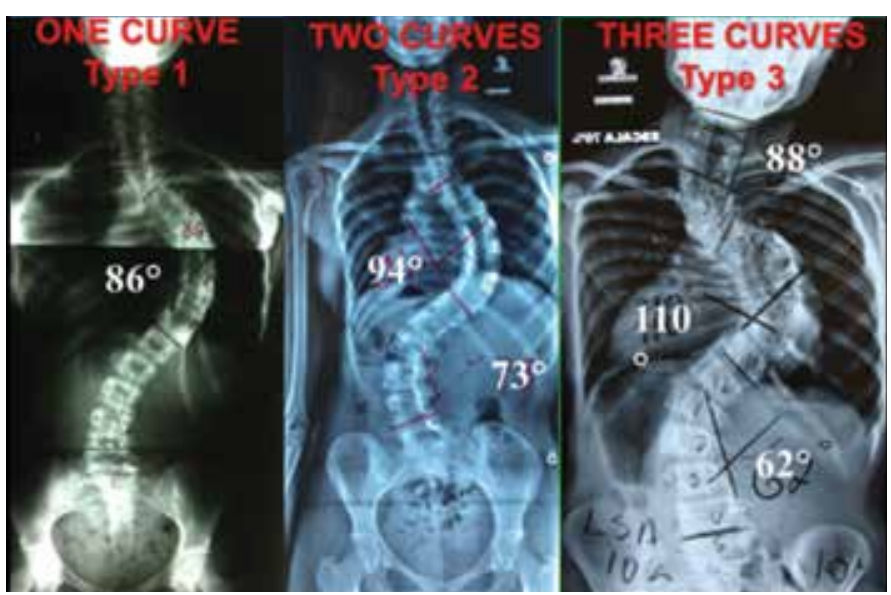

Figure 1A. First component: "Quantitative Factor" of the Three-Dimensional Classification.

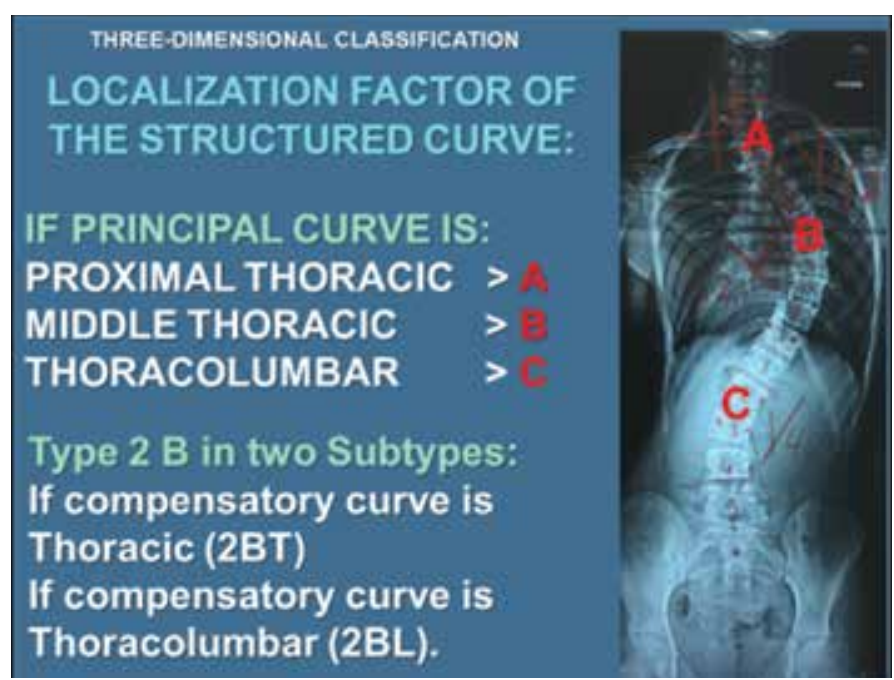

Figure 1B. Second component: "Locator Factor" of the Three-Dimensional Classification. 
is: Proximal cervicothoracic $>A$, Middle thoracic $>B$, Thoracolumbar $>\mathrm{C}$, Type $2 \mathrm{~B}$ is divided into 2 subtypes: If the compensatory curve is thoracic (2BT), If the compensatory curve is thoracolumbar (2BL).

The "Sagittal factor", the total measurement of the sagittal plane, using the Cobb method, considering the entire kyphotic area, from the upper to the lower terminal vertebra, and lordosis from L1 to S1.

It is considered (-) hypokyphosis when the angle is less than $25^{\circ}$, (N) normal when the angle is between $25^{\circ}$ and $45^{\circ}$, and $(+)$ a hyperkyphosis deformity above $45^{\circ} .{ }^{9}$

Lumbar lordosis of the spine was measured using the Cobb method, obtained by drawing a straight line in the upper plateau of $\mathrm{L} 1$ and another in the upper surface of S1. A straight line was drawn perpendicular to these two lines forming the angle to be measured. The normal value ranges from $40^{\circ}$ to $60^{\circ}(\mathrm{N})$. An angle less than $40^{\circ}(-)$ is defined as hypolordosis and an angle greater than $60^{\circ}(+)$ corresponds to hyperlordosis. ${ }^{10}$ (Figure 1C)

Sagittal Factor. Measure the total kyphosis. Measure the lumbar lordosis L1/S1. (Cobb), Hypokyphosis, Normal, 25 to $45^{\circ}$, Hyperkyphosis, Hypolordosis, Normal, 40 to $60^{\circ}$, Hyperlordosis

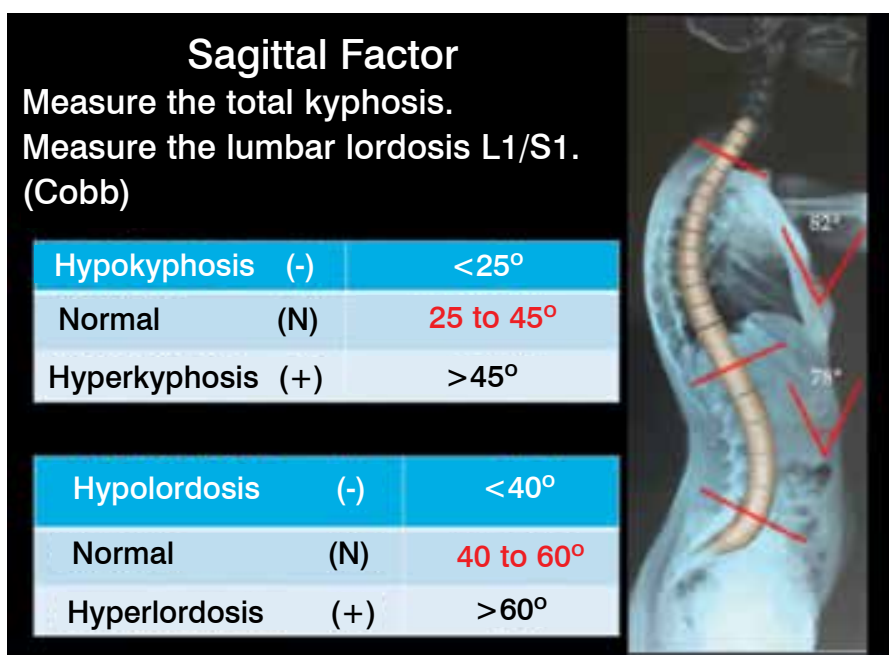

Figure 1C. Third component: "Sagittal Factor" of the Three-Dimensional Classification.

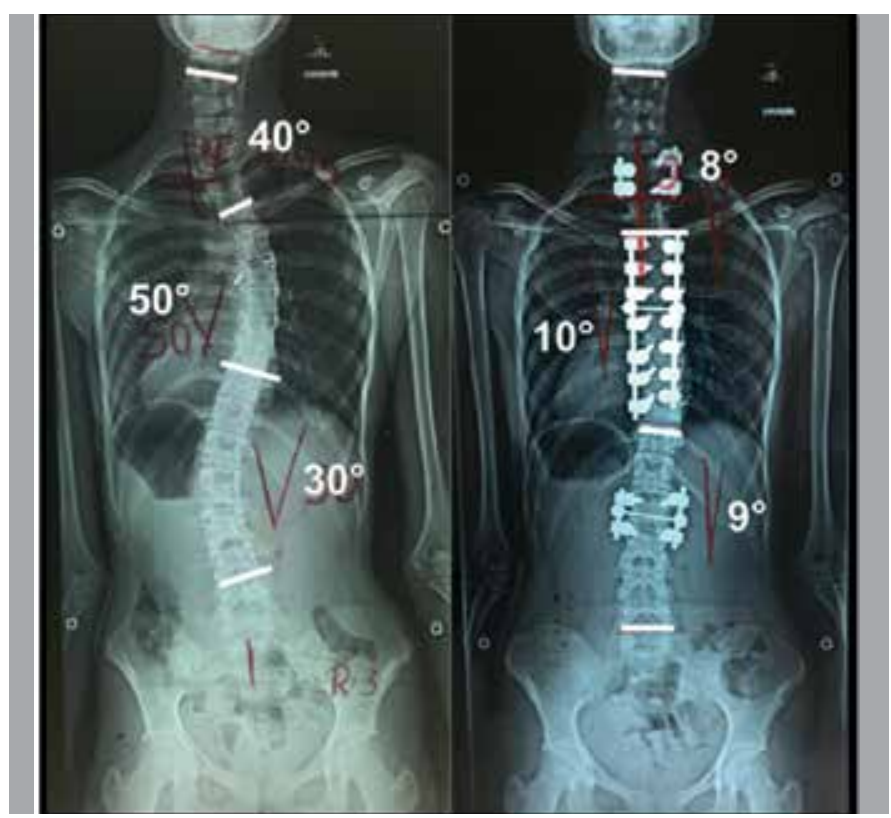

Figure 2. The above images show Three-Dimensional Classification Type 3B, the proximal curve beginning in $\mathrm{C} 3$ and terminating in T4. The apex of this curve is in $\mathrm{T} 1 / \mathrm{T} 2$, defining the level to be fixed for correction.
To test the new classification, the authors conducted a retrospective study of 99 patients randomly selected from a total of 512 cases of AIS operated in the service, comparing the Three-Dimensional and Lenke Classifications. The rest were excluded only because of the difficulty in conducting an evaluation of the entire series of cases.

For the study of the selected cases, the evaluators had the medical records and panoramic radiographs of the spine in the standing position in posterior-anterior, lateral, and posterior-anterior with right and left inclination incidences in order to analyze the flexibility and to differentiate the structural from the non-structural curves. The variables sex, color, age, Lenke 1 to 6 , and Three-Dimensional 1 to 3 were collected first. Then, in the second stage Lenke $A, B, C$ and Three-dimensional A, B, BT, BL, and C were collected, and finally, the sagittal plane evaluated as -, $\mathrm{N}$, and + by the Lenke and Three-Dimensional methods. The data were loaded into an Excel spreadsheet for the biostatistical study.

The inter- and intraclass correlation coefficients (ICC) and the Kappa coefficient were applied to measure the concordance of the three evaluators in relation to the Three-Dimensional and Lenke Classifications of the patients with idiopathic scoliosis, with a confidence interval of $95 \%$

The results of the Kappa coefficient of agreement were classified in accordance with Landis \& Koch (1977):

The research data were analyzed by the SPSS, version 20

\begin{tabular}{|c|c|}
\hline $\begin{array}{c}\text { Value of the Kappa coefficient of } \\
\text { agreement }\end{array}$ & Classification \\
\hline$<0.20$ & Poor \\
\hline 0.21 to 0.40 & Weak \\
\hline 0.41 to 0.60 & Moderate \\
\hline 0.61 to 0.80 & Good \\
\hline$>0.80$ & Very good \\
\hline
\end{tabular}

statistical program. In all the statistical tests, a level of significance of $5 \%$ was used. Thus, associations with a p-value less than 0.05 were considered statistically significant. ${ }^{12}$

\section{RESULTS}

It was necessary to evaluate the Lenke and Three-Dimensional Classifications in three separate moments. The first moment was based solely on the numeric values from 1 to 6 in order to be able to apply the technique of interclass correlation in the Lenke method. A numeric scale of 1 to 3 was considered when the technique was applied to the Three-Dimensional method. For the second moment the categories were grouped into $A, B$, and $C$ for the Lenke method and $\mathrm{A}, \mathrm{B}, \mathrm{BL}, \mathrm{BT}$, and $\mathrm{C}$ for the Three-Dimensional method so the Kappa coefficient could be applied. Finally, the categories were grouped into -, N, and + so the Kappa coefficient could be applied.

Intraclass reliability, used to measure evaluator agreement, concomitantly between the patients with idiopathic scoliosis in terms of the Lenke Classification and, subsequently in terms of the Three-Dimensional Classification, showed a correlation coefficient of 0.867 [Cl of 95\% from 0.814 to 0.907 ] in the Lenke method, representing very good agreement. In terms of the Three-Dimensional Classification, the correlation coefficient of 0.854 [Cl of $95 \%$ from 0.796 to 0.897 ] indicated very good agreement.

Interobserver reliability, used to measure the agreement between two evaluators in patients with idiopathic scoliosis according to the Lenke Classification, presented a correlation from 0.597 to 0.740 , indicating good concordance between the groups of two evaluators. (Table 1)

Table 1. Interobserver reliability to measure the agreement between two evaluators in patients with idiopathic scoliosis according to the Lenke Classification (1 to 6$)$

\begin{tabular}{c|c|c}
\hline $\begin{array}{c}\text { Lenke intercorrelation } \\
\text { (numeric scale) }\end{array}$ & Evaluator 2 & Evaluator 3 \\
\hline Evaluator 1 & 0.597 & 0.716 \\
\hline Evaluator 3 & 0.740 & - \\
\hline
\end{tabular}


Interobserver reliability, used to measure the agreement between two evaluators in patients with idiopathic scoliosis according to the Three-Dimensional Classification, presented a correlation from 0.575 to 0.744 , indicating good concordance between the groups of two evaluators. (Table 2)

The agreement between the observers according to the Lenke Classification in the A, B, and C categories was significant ( $p$ value $<0.05)$ in all situations, but was nonetheless considered moderate $(0.41<\mathrm{K}<0.61)$. (Table 3$)$

The agreement between the observers according to the Three-Dimensional Classification in the $\mathrm{A}, \mathrm{B}, \mathrm{BL}, \mathrm{BT}$, and $\mathrm{C}$ categories was significant ( $p$ value $<0.05$ ) in all situations and was considered good $(0.61<\mathrm{K}<0.80)$. (Table 3 )

The agreement between the observers according to the Lenke Classification of the sagittal plane in categories -, $\mathrm{N}$, and + was significant ( $p$ value $<0.05$ ) in all situations and was considered very good $(K>0.80)$ by the evaluators. (Table 4 )

The agreement between the observers according to the Three-Dimensional Classification of the sagittal plane in categories -, $\mathrm{N}$, and + was significant ( $p$ value $<0.05$ ) in all situations and was considered very good $(K>0.80)$ by the evaluators. See Table 4

We confirmed that there is a significant difference between the Lenke and Three-Dimensional method percentages for the evaluation of the sagittal plane in the + and Normal categories, since the $p-v a-$ lue was less than 0.05 . Therefore, it can be said that the percentages of + in the Three-Dimensional method (26.6\%) is significantly greater that the Lenke method (6.06\%), while the latter presented a higher

Table 2. Interobserver reliability to measure the agreement between two evaluators in patients with idiopathic scoliosis according to the Three-Dimensional Classification (1 to 3 ).

\begin{tabular}{c|c|c}
\hline $\begin{array}{c}\text { Three-Dimensional } \\
\text { Intercorrelation (numeric scale) }\end{array}$ & Evaluator 2 & Evaluator 3 \\
\hline Evaluator 1 & 0.744 & 0.575 \\
\hline Evaluator 3 & 0.665 & -- \\
\hline
\end{tabular}

percentage $(84.18 \%)$ in the Normal $(\mathrm{N})$ category as compared to the Three-Dimensional method (61.6\%). Table 5 and Figure 3.

Below, Figures 4 to 13 show images of ten different Types of AIS, identified by the Three-Dimensional Classification proposed by the authors.

\section{DISCUSSION}

The authors of this work, operating on a large number of clients with AIS using short, apical, single or multiple fixations, ${ }^{11}$ noted that the Lenke Classification with suggestions of fixations of the entire extension of the deformity did not fit the new fixation method. Therefore, they created the Three-Dimensional Classification in synchrony with the new fixation principle. See Figures 1 to 12

In the Three-Dimensional Classification, the proximal curve extends from the cervical spine to T5. It is opportune to measure respecting the peculiarities of each curve and it is recommended that attention be paid to curves that extend to the cervical spine to prevent coronal plane imbalance in surgical cases. (Figure 2)

The Lenke Classification covers only the 6 most common of the 10 basic types of AIS. In cases with 3 curves, if the proximal

Table 5. Analysis of the percentages between the Lenke and Three-Dimensional methods in terms of the Lenke Classification in categories -, N, and +.

\begin{tabular}{c|c|c|c|c|c|c}
\hline \multirow{2}{*}{ Variable } & \multicolumn{2}{|c|}{ Lenke Method } & \multicolumn{2}{|c|}{$\begin{array}{c}\text { Three-Dimensional } \\
\text { Method }\end{array}$} & \multirow{2}{*}{ P-value } & Conclusion \\
\cline { 2 - 6 } & $\mathbf{n}$ & $\%$ & $\mathbf{n}$ & $\%$ & & \\
\hline- & 29 & 9.76 & 35 & 11.78 & 0.427 & equal \\
\hline+ & 18 & 6.06 & 79 & 26.6 & $<0.001$ & $\begin{array}{c}\text { Three- } \\
\text { Dimensional }> \\
\text { Lenke }\end{array}$ \\
\hline $\mathrm{N}$ & 250 & 84.18 & 183 & 61.62 & $<0.001$ & $\begin{array}{c}\text { Lenke }>\text { Three- } \\
\text { Dimensional }\end{array}$ \\
\hline Total & 297 & 100 & 297 & 100 & & \\
\hline
\end{tabular}

The two proportion z test considering a scale of -, $\mathrm{N}$, + was applied.

Table 3. Analysis of the agreement of the evaluators between the patients with idiopathic scoliosis in terms of the Lenke Classification in the A, B, and C categories and in terms of the Three-Dimensional Classification in the A, B, BL, BT, and C categories.

\begin{tabular}{|c|c|c|c|c|c|}
\hline $\begin{array}{c}\text { Lenke Classification of Idiopathic Scoliosis in } \\
\text { categories A, B, and C }\end{array}$ & $\mathbf{N}$ & Kappa coeff. & $\mathrm{Cl}$ of $95 \%$ & $P$ value & $\begin{array}{l}\text { Classification of } \\
\text { concordance }\end{array}$ \\
\hline Evaluator $1 \times$ Evaluator 2 & 99 & 0.618 & $0.493 ; 0.742$ & $0.000^{\star \star}$ & Good \\
\hline Evaluator $1 \times$ Evaluator 3 & 99 & 0.605 & $0.475 ; 0.735$ & $0.000^{* *}$ & Moderate \\
\hline Evaluator $2 \times$ Evaluator 3 & 99 & 0.594 & $0.467 ; 0.722$ & $0.000^{\star \star}$ & Moderate \\
\hline \multicolumn{6}{|l|}{$\begin{array}{c}\text { Three-Dimensional Classification of Idiopathic } \\
\text { Scoliosis in categories A, B, BL, } \\
\text { BT, and C }\end{array}$} \\
\hline Evaluator $2 \times$ Evaluator 3 & 99 & 0.706 & $0.594 ; 0.818$ & $0.000^{* *}$ & Good \\
\hline
\end{tabular}

Only qualitative criteria were used in the Lenke method, with a scale of A, B, and C. Only qualitative criteria were used in the Three-Dimensional method, with a scale of A, B, BL, BT, and C.

Table 4. Analysis of the agreement of the evaluators between the patients with idiopathic scoliosis in terms of the Lenke and Three-Dimensional Classifications in the,$- \mathrm{N}$, and + categories.

\begin{tabular}{|c|c|c|c|c|c|c|}
\hline $\begin{array}{c}\text { Lenke Classification of Idiopathic Scoliosis in } \\
\text { categories -, N, and }+\end{array}$ & $\mathbf{N}$ & $\begin{array}{l}\text { Kappa } \\
\text { coeff. }\end{array}$ & \multicolumn{2}{|r|}{$\mathrm{Cl}$ of $95 \%$} & $P$ value & $\begin{array}{l}\text { Classification of } \\
\text { concordance }\end{array}$ \\
\hline Evaluator $1 \times$ Evaluator 2 & 99 & 0.965 & \multicolumn{2}{|r|}{$0.897 ; 1.00$} & $0.000 * *$ & Very Good \\
\hline Evaluator $1 \times$ Evaluator 3 & 99 & 0.925 & \multicolumn{2}{|r|}{$0.821 ; 1.00$} & $0.000 * *$ & Very Good \\
\hline Evaluator $2 \times$ Evaluator 3 & 99 & 0.89 & \multicolumn{2}{|r|}{$0.768 ; 1.00$} & $0.000 * *$ & Very Good \\
\hline \multicolumn{7}{|l|}{$\begin{array}{l}\text { Three-Dimensional Classification of Idiopathic } \\
\text { Scoliosis in categories -, N, and + }\end{array}$} \\
\hline Evaluator $1 \times$ Evaluator 2 & 99 & & 0.853 & $0.756 ; 0.949$ & $0.000 * *$ & Very Good \\
\hline Evaluator $1 \times$ Evaluator 3 & 99 & & 0.845 & $0.743 ; 0.947$ & $0.000 * *$ & Very Good \\
\hline Evaluator $2 \times$ Evaluator 3 & 99 & & 0.813 & $0.703 ; 0.923$ & $0.000 * *$ & Very Good \\
\hline
\end{tabular}

Only qualitative criteria were used in the Lenke method, with a scale of,$- \mathrm{N}$, and + . Only qualitative criteria were used in the Three-Dimensional method, with a scale of,$- \mathrm{N}$, and + . 


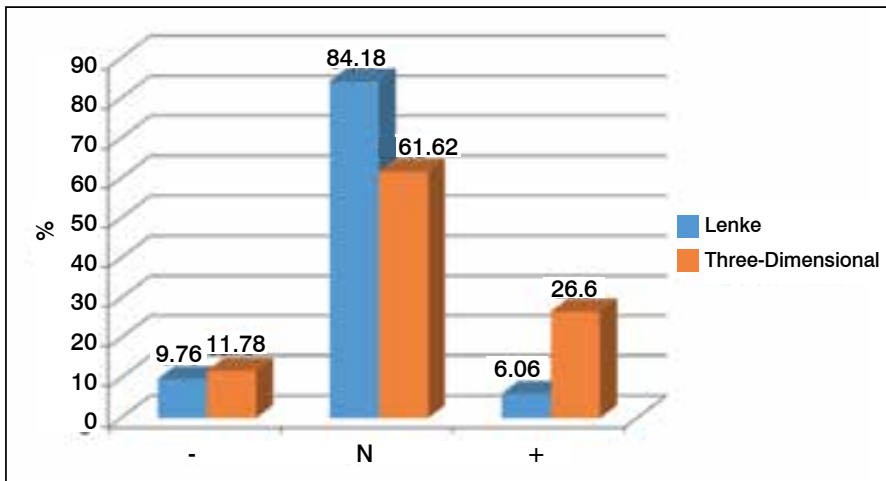

Figure 3. Analysis of the percentages between the Lenke and Three-Dimensional Classification in the -, $\mathrm{N}$, and + categories.

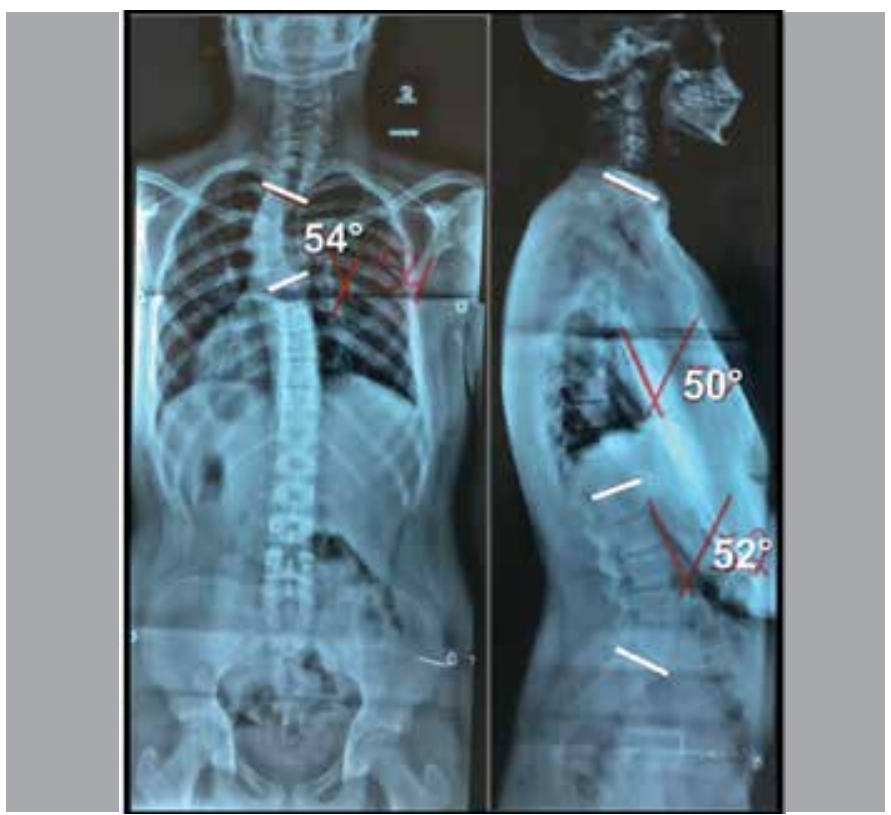

Figure 4. Image showing a single structural proximal curve, Type $1 \mathrm{~A}+\mathrm{N}$.

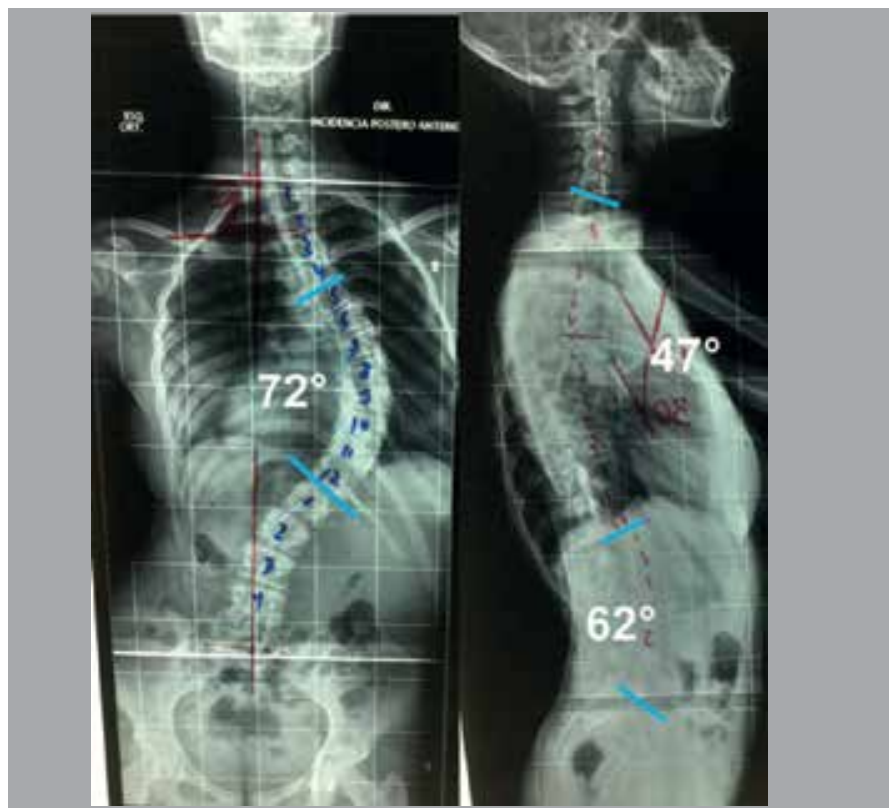

Figure 5. Image showing a single structural middle thoracic curve, Type 1 $\mathrm{B}++$.

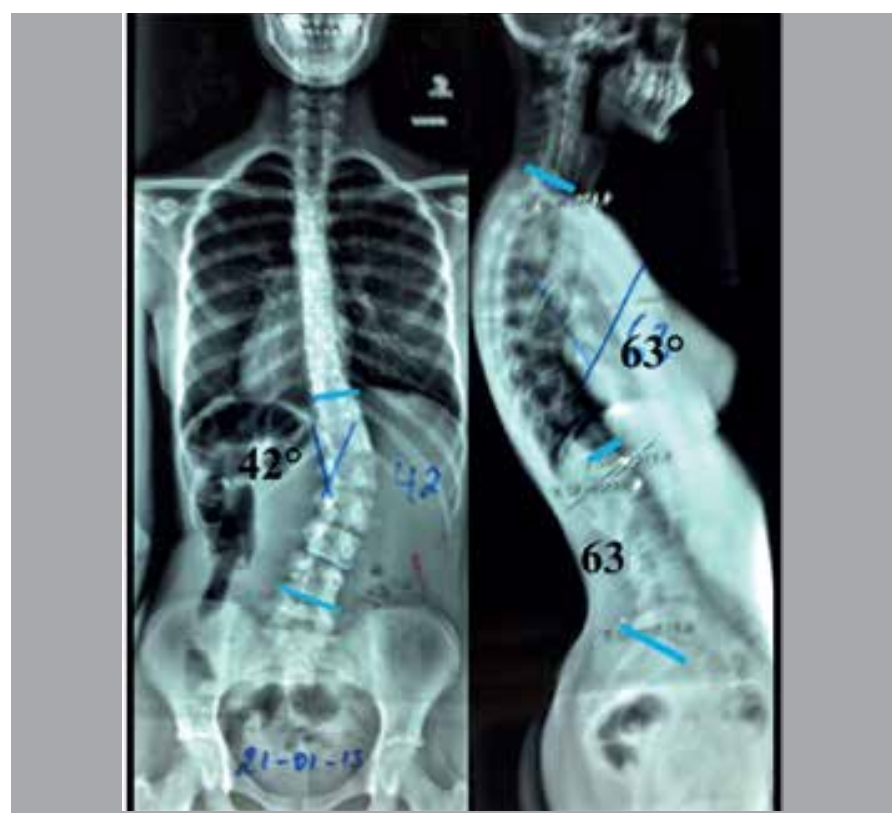

Figure 6. Image showing a single structural thoracolumbar curve Type 1 C + +

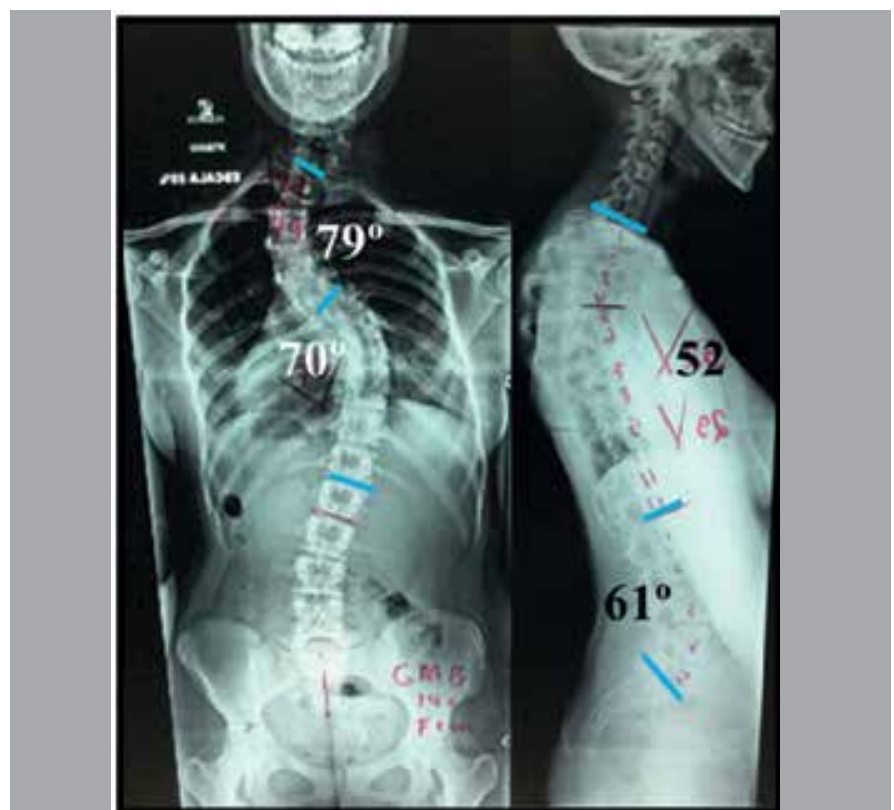

Figure 7. Case with two curves. The proximal curve is the main curve and the middle thoracic curve is the compensatory curve, therefore, Type $2 \mathrm{~A}++$

or thoracolumbar curve is the main curve, they do not fit into the method. See Figures 11 to 13. If the patient has two curves located in the thoracic spine, the proximal being the main curve, it does not fit into the method. (Figure 7) In cases with only one structural curve, if it is proximal, once again it does not fit into the method. (Figure 4)

The lumbar spine modifier of the Lenke Classification, identified as $A, B$, or $C$, is based on the relationship between the central sacral vertical line and the apex of the lumbar curve. Therefore, as types 1 and 2 do not have a lumbar curve, they are not applicable and types 5 and 6 are always considered $\mathrm{C}$. Therefore, this lumbar modifier is only applied to types 3 and 4 . The corresponding factor in the Three-Dimensional Classification, called the locator factor with possible values of $A, B, B T$, $\mathrm{BL}$, and $\mathrm{C}$ is always applied, informing us of the location of the main and most structural curve in all forms of AIS and similar conditions

In some of the lateral images in patients in this series it is very difficult to see T5 due to the superimposed scapula, therefore, another argument against the option of using $T 5$ as a reference, especially in cases of 


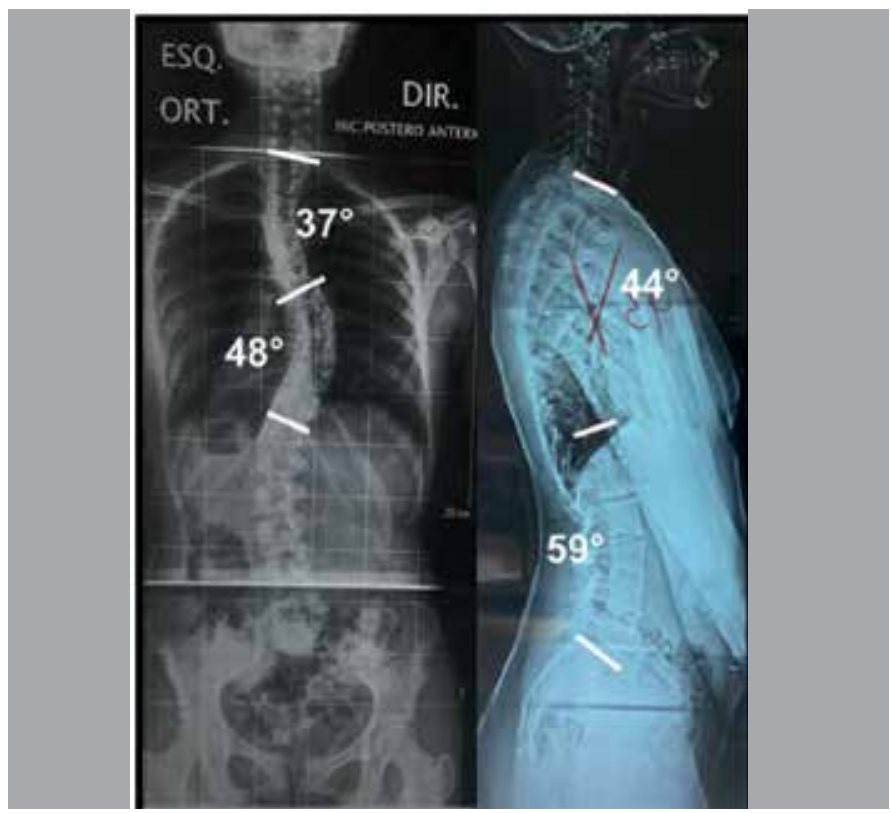

Figure 8. Case with two curves. The middle thoracic curve is the main curve and the proximal curve is the compensatory curve, therefore, Type 2 BT N N.

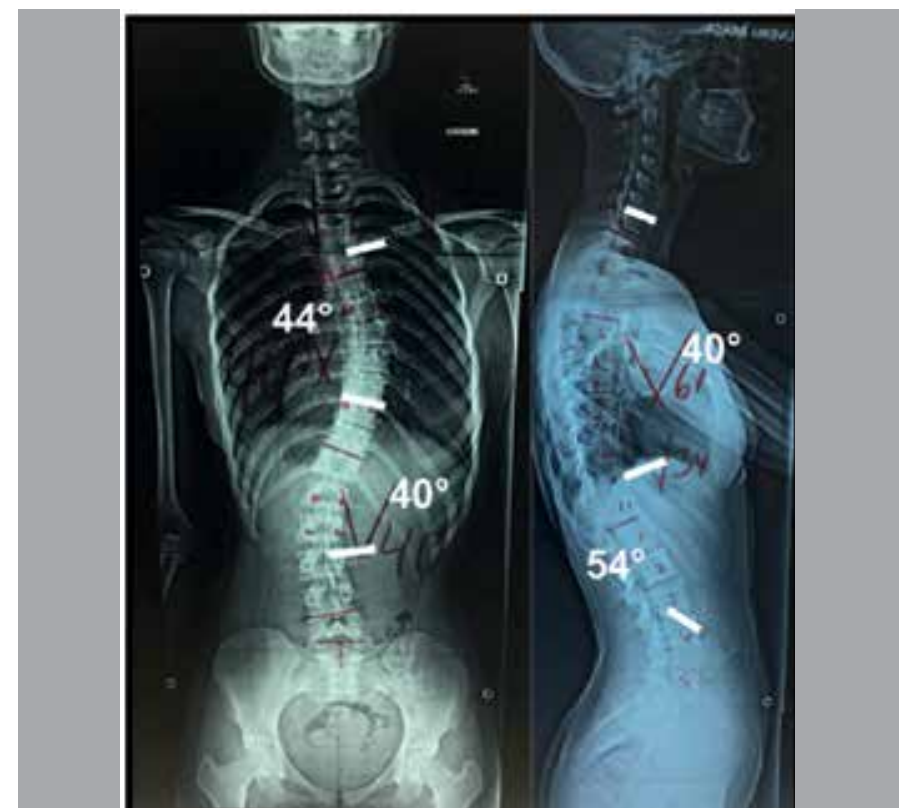

Figure 9. Case with two curves. The middle thoracic curve is the main curve and the thoracolumbar curve is the compensatory curve, therefore, Type 2 BL N N.

hypolordosis and normality of the dorsal sagittal plane. See Figures 4 to 12.

The Lenke Classification standardized the measurement of T5 to T12, not respecting the peculiarity of each curve, since frequently the apex of kyphosis is located exactly at T5. In the Three-Dimensional Classification the entire extension of kyphosis is measured, from the upper plateau of the upper terminal vertebra to the lower plateau of the lower terminal vertebra. ${ }^{9}$ Figures $1 \mathrm{C}$ and 4 to 13.

The results from this case series of 99 patients relating to the angle of kyphosis using the Lenke Classification showed only $6.06 \%$ with hyperkyphosis $(+)$ and $84.18 \%$ considered normal $(N)$, while the Three-Dimensional Classification presented $26.6 \%$ with hyperkyphosis $(+)$ and $61.6 \%$ as normal $(\mathrm{N})$, which leads us to believe that the range considered as normal by Lenke, from $10^{\circ}$ to $40^{\circ}$, may be exceedingly broad. Table 5 and Figure 3.

No doubt the Three-Dimensional Classification needs additional testing. In this work, we conducted a comparative study of the

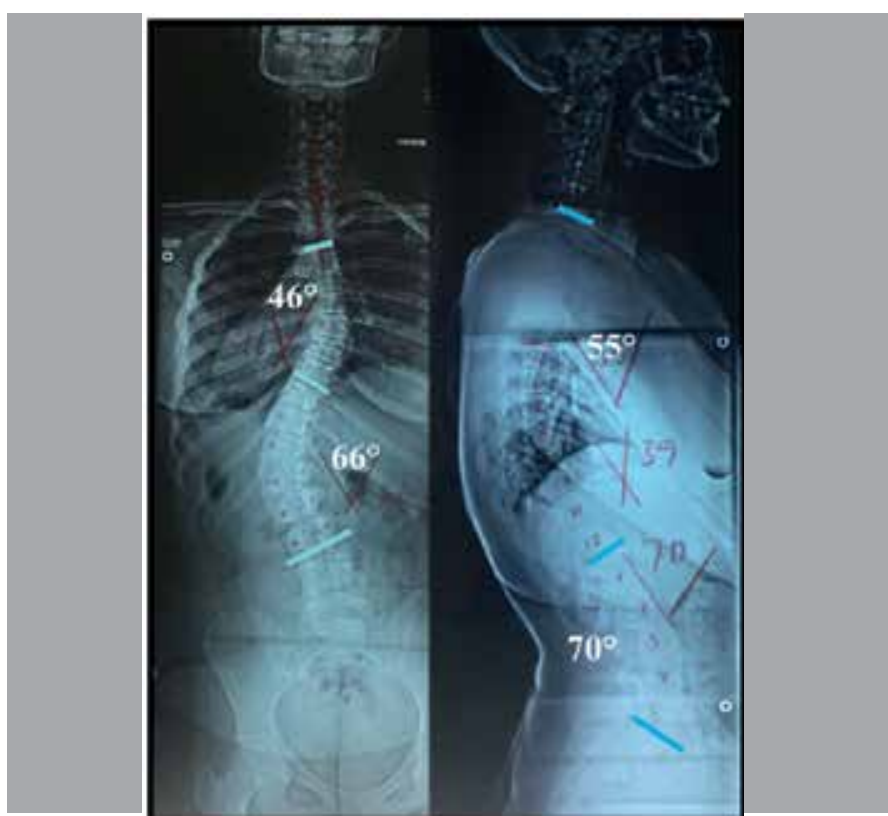

Figure 10. Case with two curves. The thoracolumbar curve is the main curve and the middle thoracic curve is the compensatory curve, therefore, Type $2 \mathrm{C}++$

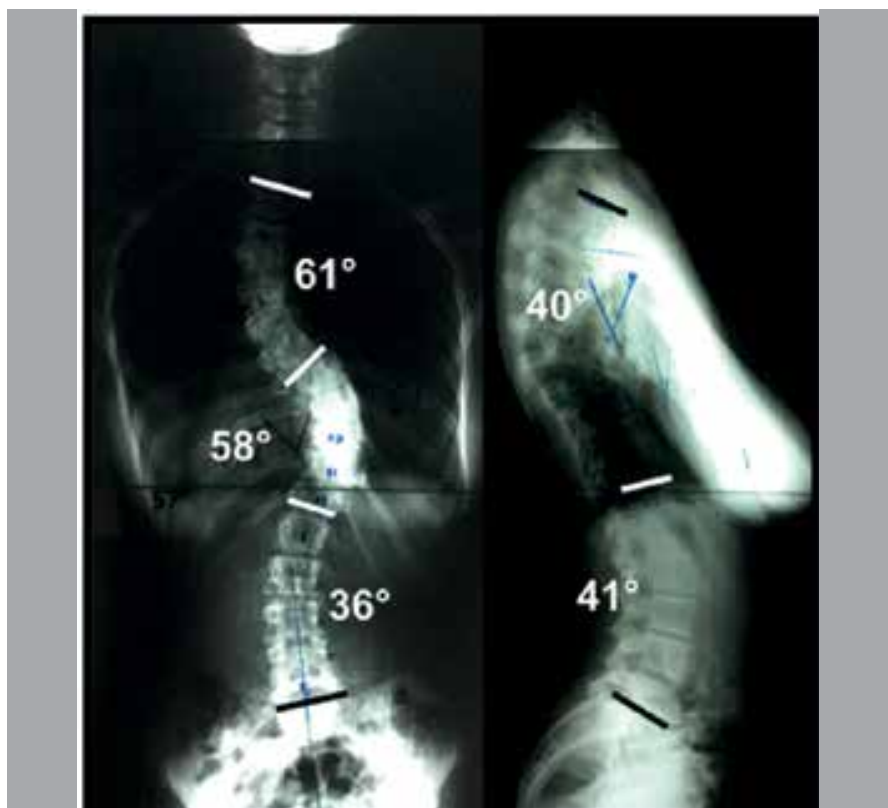

Figure 11. Patient presenting three curves. The proximal thoracic curve is the main curve, called Type 3 A N N.

Three-Dimensional and Lenke Classifications in which lordosis was not compared because it is not included in the Lenke method.

\section{CONCLUSIONS}

In the study of this case series there was a significant difference between the two classifications in the percentages. The Three-Dimensional Classification of the sagittal plane resulted in $26.6 \%$ hyperkyphosis and $61.6 \%$ normal, while the Lenke Classification yielded $6.06 \%$ hyperkyphosis and $84.18 \%$ normal. However, in the overall comparative analysis, the Three-Dimensional and Lenke methods presented levels of agreement that were statistically the same, since the values of the confidence intervals overlap.

All authors declare no potential conflict of interest related to this article. 


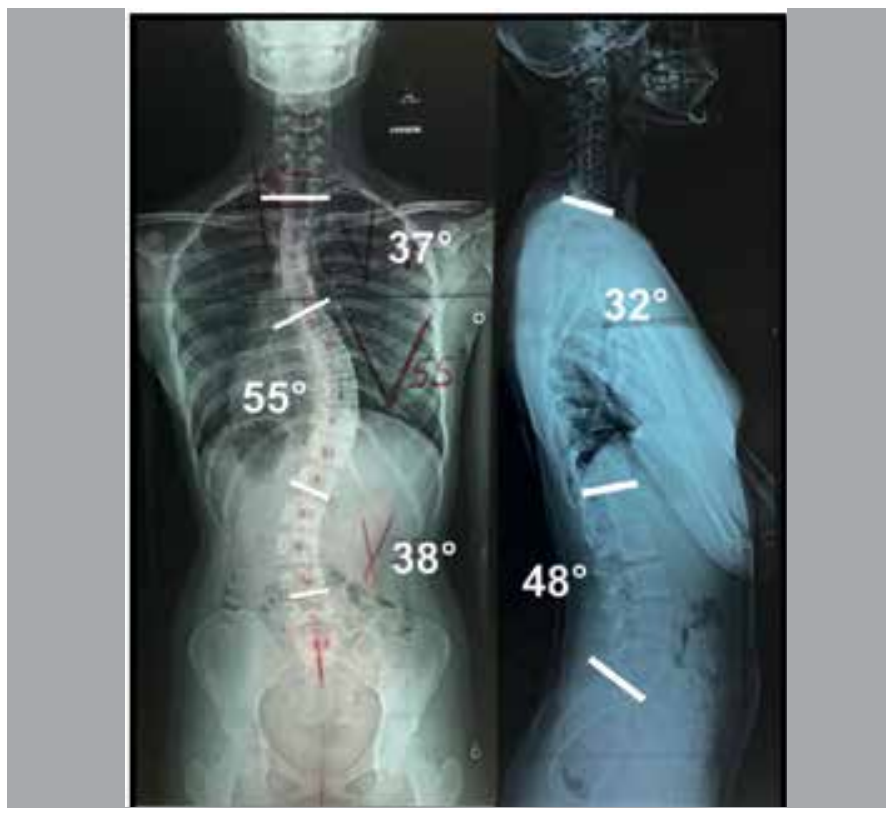

Figure 12. Patient presenting three curves. The middle thoracic curve is the main curve, called Type 3 B N N.

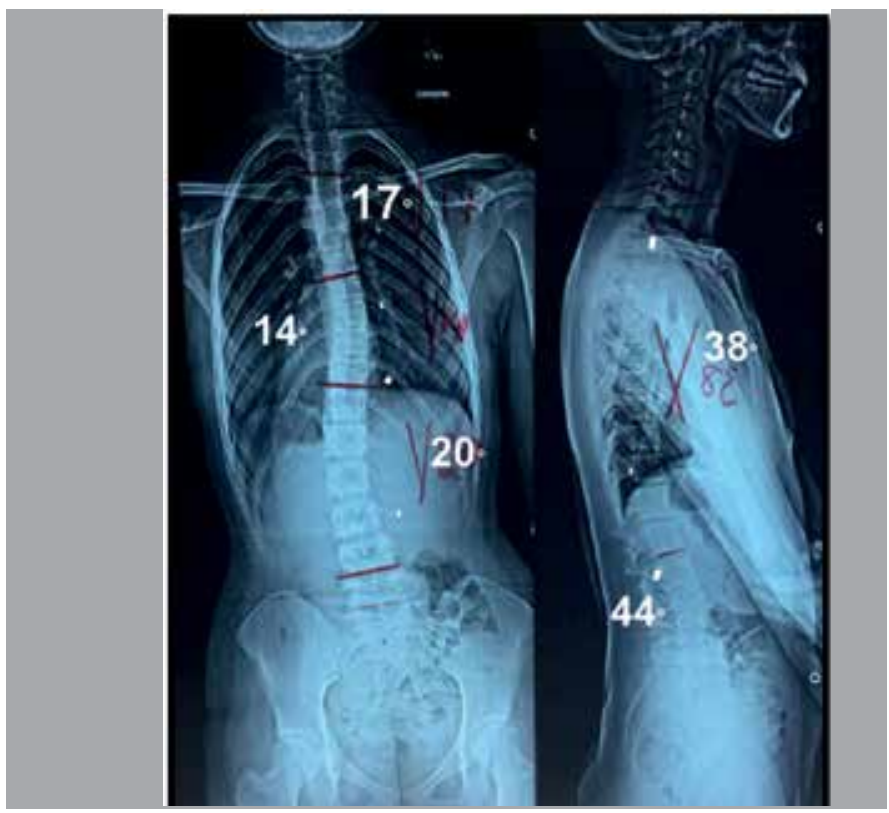

Figure 13. Patient presenting three curves. The thoracolumbar curve is the main curve, called Type 3 C N N.

CONTRIBUTION OF THE AUTHORS: Each author made significant individual contributions to this manuscript. EBG (0000-0002-1737-7811)* was the main author. LFG (0000-0002-2425-8802)*, EBGJ (0000-0002-7612-2579)*, JGC (0000-0003-4054-0821)*, and MFC (0000-0001-9741-1727)* contributed to the preparation of the manuscript. LGV $(0000-0003-2031-814 x)^{\star}$, RGG $(0000-0003-0376-8763)^{\star}$, EDU $(0000-0002-3447-0014)^{\star}$, STG $(0000-0002-8482-479 X)^{\star}$, and VOM (0000-0001-8808-4787)* reviewed the article. *ORCID (Open Researcher and Contributor ID).

\section{REFERENCES}

1. Bernhardt M, Bridwell KH. Segmental analysis of the sagittal plane alignment of the normal thoracic and lumbar spines and thoracolumbar junction. Spine (Phila Pa 1976). 1989;14(7):717-21.

2. Cummings RJ, Loveless EA, Campbell J, Samelson S, Mazur JM. Interobserver reliability and intraobserver reproducibility of the system of King et al. for the classification of adolescent idiopathic scoliosis. J Bone Joint Surg Am. 1998;80(8):1107-11.

3. Ward WT, Rinn JA, Solic J, Lee JY. A comparison of the Lenke and king classification systems in the surgical treatment of idiopathic thoracic scoliosis. Spine (Phila Pa 1976). 2008;33(1):52-60.

4. Schulthess W. Die pathologie und therapie der rückgratsverkrümmungen. In: Joachimsthal G. Handbuch der orthopädischen chirurgie. Jena: Gustav Fischer: 1905-1907. v. 1, pt 2.

5. King HA, Moe JH, Bradford DS, Winter RB. The selection of fusion levels in thoracic idiopathic scoliosis. J Bone Joint Surg Am. 1983;65(9):1302-13.

6. Lenke LG, Betz RR, Harms J, Bridwell KH, Clements DH, Lowe TG, et al. Adolescent idiopathic scoliosis: a new classification to determine extent of spinal arthrodesis. J Bone Joint Surg Am. 2001;83-A(8):1169-81.
7. Vialle EM, Vialle LR, Martins Filho de Jorge RM Confiabilidade de uma versão em português da Classificação de Lenke para Escoliose Idiopática do Adolescente. Coluna/Columna. 2006:5(12):1737-838.

8. Silveira RT, Payão GB, Garcia EB, Gonçalves RG, Garcia Júnior EB, Garcia JF, et al. Prevalência das curvas da Classificação de Lenke para escoliose idiopática do adolescente: estudo comparativo. Coluna/Columna. 2008:7(3)270-5.

9. Moreira JJM, Fuentes ERA, Corrêa PHC. Estudo radiológico do valor angular da cifose torácica em adolescentes. Coluna/Columna. 2010:9(4):353-7.

10. Kapandji IA. Fisioterapia articular: tronco e coluna vertebral. 5a ed. Rio de Janeiro: Guanabara Koogan; 2000.

11. Garcia EB, Garcia LF, Garcia Júnior EB, Camarinha MF, Camarinha JG, et al. Escoliose idiopática do adolescente: fixações curtas, apicais, únicas ou múltiplas. [PRELO]

12. Koch GG, Landis JR, Freeman JL, Freeman DH Jr, Lehnen RC. A general methodology for the analysis of experiments with repeated measurement of categorical data. Biometrics. 1977;33(1):133-58.WW 